\title{
Ustawowe i nieustawowe prawo pracy
}

\section{Uwagi wstępne}

olskie prawo pracy jest w znakomitej większości prawem ustawo$\int$ wym. Dowodzi tego choćby praktyka sądowa, która stosunkowo rzadko dokonuje rozstrzygnięć na podstawie tzw. źródeł autonomicznych. Na czele prawa ustawowego znajduje się oczywiście kodeks pracy. Istnienie $\mathrm{w}$ systemie prawnym pracy kodeksu, czyli aktu $\mathrm{w}$ miarę możliwości uniwersalnego, jest symbolem ustawodawczej dominacji w procesie tworzenia prawa pracy. Czasem jest on powodem do dumy, zwłaszcza gdy wskazuje się na państwa zachodnioeuropejskie, gdzie kodeks nie jest zjawiskiem powszechnym. Czasem jest to powód do zmartwień, gdy z zazdrością przyglądamy się rozbudowanej w innych krajach praktyce układowej. Z powyższych powodów warto - w pracy poświęconej przyszłości prawa pracy - zatrzymać się nieco nad ustawową techniką regulacji stosunków społecznych związanych z praca, w kontekście ich wad i zalet, w szczególności na tle prawa pozaustawowego.

\section{Publiczne a ustawowe prawo pracy}

Rozważania nad ustawowym prawem pracy warto rozpocząć od zarysowania jego relacji do tzw. autonomicznych źródeł prawa pracy. Przy czym nie interesują mnie $\mathrm{w}$ tym miejscu klasyczne już rozważania dotyczące tzw. hierarchii źródeł oraz zasady korzystności, interesuje mnie pytanie, w czyim imieniu powstają ustawy, a także w czyim imieniu powstają autonomiczne źródła prawa.

Przypomnijmy, że zgodnie $\mathrm{z}$ dominującymi w doktrynie i orzecznictwie poglądami, tzw. autonomiczne źródła prawa pracy są źródłami

* Prof. dr hab., Katedra Prawa Pracy i Polityki Społecznej, Wydział Prawa i Administracji Uniwersytetu Jagiellońskiego. 
prawa. Z powyższym poglądem polemizowałem twierdząc, że mają one najczęściej charakter umów. Wyrażałem wtedy przekonanie, że ten fragment prawa pracy ma charakter prywatny. Ponadto, w zastanych wypowiedziach nie znajdowałem jasnej odpowiedzi na pytanie, jaki charakter prawny mają akty tworzenia prawa, skoro dokonywane były przez podmioty prywatne. Wreszcie, poszukiwałem prawa, które postrzegałem jako substytut ustawy.

Od tego czasu moje poglądy uległy całkowitej ewolucji. Odstąpiłem bowiem od poglądu, że prawo pracy jest prawem częściowo prywatnym a częściowo publicznym. Obecnie, po uznaniu przeze mnie prawa pracy za prawo praktycznie w całości publiczne, prawny charakter tzw. autonomicznych źródeł prawa stał się dość oczywisty. W ramach prawa publicznego, a precyzyjniej - administracyjnego, pracodawca oraz partnerzy społeczni mogą wydawać akty prawa publicznego. Tym samym proces tworzenia autonomicznego prawa pracy jest w moim przekonaniu procesem publicznym. A czynności ustanawiające lokalne prawo pracy są aktami administracyjnymi, a nie czynnościami prawnymi. Konsekwentnie, autonomiczne źródła prawa pracy mają charakter generalnych aktów administracyjnych, a nie quasi ustaw.

Powyższe stwierdzenie konweniuje zresztą z konstatacją zgodnie 308 z którą osoby związane z zakładem pracy stanowią wspólnotę ${ }^{1}$. W ramach wspólnot mogą bowiem występować akty generalne, zwłaszcza tam, gdzie wewnętrzne regulacje wprowadzane są $\mathrm{w}$ formułach niedemokratycznych lub w postaci demokracji pośredniej. A takie właśnie formuły podejmowania decyzji zachodzą w zakładzie pracy. Konsekwencją takiej perspektywy jest twierdzenie, że zarówno ustawowe prawo pracy, jak i to autonomiczne, mają charakter publiczny. Tak ustawy, jak i prawo autonomiczne wprowadzane są bowiem w życie w drodze aktów prawa publicznego.

W dalszej części rozważań skupiam się na prawie ustawowym, starając się ocenić jego efektywność. Jednak ukazując bariery jego rozwoju wskazuję na atuty prawa autonomicznego.

\section{Ustawowe prawo pracy a zasada równości}

Państwo związane jest konstytucyjną zasadą równości. A skoro pracodawca lub partnerzy społeczni w zakładach pracy dokonują aktów publicznych, czyli w imieniu państwa, to także oni związani są powyższą zasadą. Konsekwentnie, prawo publiczne musi wszystkich jego adresa-

${ }^{1} \mathrm{Na}$ temat wspólnotowości zakładu pracy piszę więcej w A. Sobczyk, Wspólnota zakładu pracy jako emanacja społecznej gospodarki rynkowej, „Praca i Zabezpieczenie Społeczne” 2015, z. 4. 
tów traktować równo. Przy czym równość trzeba rozumieć także jako tzw. równość w prawie, czyli wyrównywanie normami asymetrycznymi sytuacji podmiotów nierównych.

Rzecz w tym, że inna jest przestrzeń społeczna (punkty odniesienia) dla ustawodawcy, a inna dla pracodawcy (partnerów społecznych). Państwo musi zapewnić prawo traktujące równo wszystkich zatrudnionych, wszystkich zatrudniających oraz wszystkich zatrudnionych w relacji do pracodawców konstytucyjnych. Nie muszę oczywiście na tym poziomie rozważań rozwijać wątku, iż równość wobec prawa nie jest tożsama z identycznością sytuacji prawnej. Tymczasem autonomiczne prawo pracy musi zapewnić równość tylko swoim adresatom, czyli najczęściej pracownikom. Przynajmniej w chwili obecnej nie dostrzegam przykładów, w których autonomiczne prawo pracy mogłoby naruszyć zasadę równości pomiędzy pracownikami a pracodawcami konstytucyjnymi lub pomiędzy pracodawcami konstytucyjnymi. Szczególnie, że ci ostatni wdrażaja powyższe prawo poprzez swoje organy. Jednak całkowicie tego nie wykluczam. Wyrażam bowiem pogląd, że organy osób prawnych tworząc lub negocjując autonomiczne prawo pracy nie występują $\mathrm{w}$ roli cywilnego przedstawiciela udziałowców lub akcjonariuszy, lecz jako osoby wyposażone we władztwo publiczne. Tym samym kształtują sytuację prawną akcjonariuszy bądź wspólników na podstawie normy kompetencyjnej, a nie na podstawie umocowania o charakterze cywilnym. Niemniej jednak ten ostatni wątek nie jest tu kluczowy.

Wracając jednak do prawa ustawowego - znacznie łatwiej jest zapewnić standard równości wobec prawa w mniejszej społeczności niż w przypadku całej wspólnoty państwowej, zwłaszcza, jeśli występują wielopoziomowe zależności między ludźmi. W efekcie jest więc tak, że ustawowe prawo pracy daje znacznie mniejsze możliwości różnicowania standardów prawnych. Klasycznym przykładem może tu być ustawa o tzw. zwolnieniach grupowych $\mathrm{w}$ tym aspekcie, w którym dotyczy odpraw. Zgodnie $\mathrm{z}$ aktualnym brzmieniem ustawy, pracodawca zatrudniający mniej niż 20 pracowników nie ma obowiązku ich wypłaty, jeśli wypowie umowę o pracę z przyczyn niedotyczących pracownika. Różnicuje to więc sytuację prawną pracownika, w zależności od kryterium wielkości pracodawcy.

Problem ten wzbudził uzasadnione wątpliwości konstytucyjne, co doprowadziło do rozstrzygnięcia trybunalskiego. Trybunał stwierdził przy tym, że ustawa o zwolnieniach grupowych nie narusza konstytucyjnej zasady równości, albowiem małych pracodawców nie stać po prostu na dźwiganie tak wielkich ciężarów ${ }^{2}$. Rozumowanie TK jest trafne tylko

${ }^{2}$ Wyrok TK z dnia 24.04.2004, sygn. akt K 54/02, DzU, 2004 nr 40, poz. 374; „Monitor Prawniczy" 2004, nr 6, s. 246, „Orzecznictwo Trybunału Konstytucyjnego" 2004, Seria A, nr 2, poz. 10, Legalis. 
o tyle, że potencjał ekonomiczny niektórych pracodawców (mierzony przez uproszczone, ale chyba jedyne sensowne kryterium, jakim jest wielkość zatrudnienia), uzasadnia zmniejszenie ich ciężarów socjalnych. Tyle tylko, że powyższe orzeczenie nie stoi w sprzeczności $\mathrm{z}$ twierdzeniem, że stan prawny jest jednak niekonstytucyjny. Bo jeśli już zdiagnozować sens odprawy jako świadczenia socjalnego, czyli świadczenia uzasadnionego potrzebami, a nie zasługami, to pozbawienie redukowanych pracowników prawa do odpraw w sposób oczywisty narusza zasadę równości.

Rzecz nie polega bowiem na tym, aby pracownik otrzymał odprawę od pracodawcy. Odpowiedzialność za zaspokajanie potrzeb społecznych spoczywa na wspólnocie (państwowej, samorządowej lub zakładowej). Spoczywa także na rodzinie, ale akurat w kontekście odpraw nie ma to znaczenia. Dlatego wspólnota winna zapewnić pracownikowi pomoc w związku z utratą pracy. Jeśli więc zwolniliśmy z powyższego obowiązku pracodawcę, to pracownik winien ją otrzymać od państwa lub gminy. Wtedy osiągnęlibyśmy standard równości wobec prawa pracowników oraz równości wobec prawa pracodawców. Bo rzeczywiście jest tak, że obciążenia socjalne są $\mathrm{w}$ większym stopniu uciążliwe dla pracodawców małych, a w mniejszym dla dużych. Tym samym jednakowe obciążenia dla wszystkich pracodawców mają ten skutek, że niszczą konkurencyjność podmiotów małych. Pomijam już ważkie konflikty wartości, jakie występują w przypadku małych firm rodzinnych, w których socjalne potrzeby pracownika mają silniejszą ochronę prawną niż socjalne potrzeby pracodawcy i jego rodziny.

Powyższy przykład prowadzi do wniosku, że w kwestii odpraw możliwe są dwa rozwiązania. Pierwsze, o którym była już mowa, że odprawy dla pracowników zatrudnionych u małych pracodawców zostaną wypłacone przez system ubezpieczeń społecznych. Drugie jest takie, że odprawy zostaną w ogóle usunięte $\mathrm{z}$ ustawy. Tak jest zresztą $\mathrm{w}$ wielu krajach. Konsekwentnie, odprawy staną się domeną autonomicznych aktów prawa pracy, gdzie zasada równości ma inne punkty odniesienia. Odprawy wypłacą więc ci, których będzie na to stać, o ile będzie taka potrzeba. Wszak dobrze płatni pracownicy nie muszą otrzymywać odpraw. Powyższe rozwiązanie jest sensowne jeszcze o tyle, że prawdopodobieństwo wypłacania odpraw przez system ubezpieczeń społecznych jest iluzoryczne. Jednak oba rozwiązania są dobre. A trwanie w aktualnym stanie prawnym jest $\mathrm{w}$ moim przekonaniu trwaniem $\mathrm{w}$ stanie oczywistego deliktu konstytucyjnego naruszenia zasady równości.

Powyższy tok rozumowania dotyczy zresztą wszelkich potencjalnych ulg w obciążeniach dla pracodawców słabszych ekonomicznie. Bo też trzeba dodać, że nie ma jednak prostej zależności pomiędzy wielkością zatrudnienia a pozycją ekonomiczną. Słabsza ekonomicznie może być także 
potężna pod względem zatrudnienia spółka, która walczy o przetrwanie. Zresztą warto spojrzeć na inne przykłady nierówności po stronie pracodawców w kontekście ciężarów socjalnych. Najlepszym przykładem są wynagrodzenia chorobowe, które są niezwykle uciążliwe dla mikropracodawców. Promocja takich form winna następować poprzez przeniesienie ciężaru wypłaty wynagrodzenia chorobowego na ZUS (zasiłek), a nie poprzez prostą likwidację wynagrodzenia chorobowego. W ten sposób gwarantujemy standard równości pomiędzy pracodawcami (wspieramy małych pracodawców) oraz między pracownikami (każdy chory otrzyma zabezpieczenie, choć z innych źródeł).

Warto także wspomnieć, że proces likwidowania powszechnie stosowanych świadczeń nie jest czymś nowym. Mam tu na myśli nagrody jubileuszowe, które wraz z prywatyzacją stały się przedmiotem układów zbiorowych u pracodawców w miarę zamożnych, a nie występuje w zakładach słabszych. Inna rzecz, że rozwiązanie to nie cieszy się obecnie dużą popularnością z powodów podatkowych (silnie obciąża tzw. rezerwy spółek).

Podsumowując, podstawową wadą ustawowego prawa pracy jest to, że jego możliwości różnicowania sytuacji prawnej pracodawców i pracowników według kryterium wielkości pracodawcy są bardzo ograniczone. A jeśliby już chciało się takowe różnicowanie przeprowadzić w sposób głębszy, to okazałoby się, że należy powyższe silnie wesprzeć środkami publicznymi dla tych pracowników, którzy utraciliby świadczenia wypłacane przez pracodawców.

\section{Ustawowe prawo pracy a zasada proporcjonalności}

Dominująca część ustawowego prawa pracy skupia się na ingerencji w prawa i wolności ludzi w związku z wykonywaniem pracy zarobkowej lub prowadzeniem działalności gospodarczej, choć wcale nie jest oczywiste, czy pomiędzy wolnością pracy a wolnością prowadzenia działalności gospodarczej jest jakaś istotna różnica.

Powyższa konstatacja $\mathrm{z}$ perspektywy pracodawcy oznacza tyle, że ustawodawca ogranicza jego wolność lub nawet własność w imię ochrony praw pracowników. Najczęściej dotyczy to praw człowieka, czasem innych zadań i celów publicznych.

Ingerencja prawa publicznego $\mathrm{w}$ wolności i prawa indywidulane musi się jednak cechować proporcjonalnością i subsydiarnością. Wyżej, pisząc o odprawach z tytułu zwolnień z przyczyn niedotyczących pracownika, wspomniałem już o aspekcie proporcjonalności. Ustawodawca uznał bowiem, że powyższe obciążenie jest dla małego pracodawcy nadmierne. Zwłaszcza, że jest to obciążenie o charakterze fiskalnym, skoro ma charakter socjalny. 
Problem w tym, że z perspektywy mikropracodawców takich nadmiernych obciążeń jest więcej. Przy czym wspomniany wyżej problem świadczeń jest relatywnie łatwy do rozwiązania. Można bowiem zastąpić świadczenia od pracodawców świadczeniami z systemu ubezpieczeń społecznych lub budżetu. Można też materię świadczeń pozostawić do uregulowania autonomicznemu prawu pracy.

Znacznie większe problemy powstają w kontekście obowiązków publicznoprawnych polegających na obowiązku działania. Dobrym przykładem są tu regulacje dotyczące zapobiegania mobbingowi bądź dyskryminacji. Powyższe obowiązki mają w moim przekonaniu charakter publiczny i wyręczają wspólnotę państwową w zakresie ochrony człowieka przed naruszeniem jego wolności pracy. $W$ tym kontekście trudno sobie wyobrazić, że prawo mogłoby zwolnić z obowiązku przeciwdziałania pracodawców małych, choć nie jest to zupełnie wykluczone. Przeciwdziałanie nabiera przecież realnego wymiaru tam, gdzie zjawiska mają lub mogą mieć charakter anonimowy. Ale też trudno zaakceptować sytuację, aby pracodawca nie miał obowiązku przeciwdziałania np. molestowaniu tylko dlatego, że zatrudnia nieliczny zespół pracowniczy.

Problem jednak w tym, że przeciwdziałanie kwalifikowanemu naruszaniu dóbr osobistych nie zawsze jest proste. Czasem wymaga trudnego procesu ustalenia stanu faktycznego oraz oceny wiarygodności uczestniczących w nim osób. Czasem zaś wymaga poważnego i kosztownego wsparcia prawnego. A błąd w ocenie sytuacji może się wiązać z szeregiem istotnych konsekwencji materialnych lub osobistych. $Z$ tej perspektywy nałożony na małych pracodawców obowiązek publiczny jest trudny do udźwignięcia, przy równoczesnych znacznych ryzykach prawnych. A w związku z tym zarzut niedochowania przez ustawodawcę zasady proporcjonalności brzmi bardzo poważnie.

Zresztą powyższy tok rozumowania można przeprowadzić np. na tle obowiązków związanych z archiwizacją akt. Wszak zatrudnienie przez pracodawcę jednej osoby na kilka dni ma taki dla niego skutek, że przez kilkadziesiąt lat musi on przechowywać akta osobowe, i to w warunkach zapewniających ich bezpieczeństwo.

We wskazanych wyżej wypadkach trudno przyjąć rozwiązanie, które sprowadziłoby się do całkowitego usunięcia z systemu prawa powyższych obowiązków, choć w przypadku przeciwdziałania naruszaniu dóbr osobistych jest to teoretycznie możliwe. Wszak przez lata nie mieliśmy regulacji prawnej w tym zakresie.

Dlatego potencjalny zarzut nieproporcjonalności można uchylić wyłącznie w ten sposób, że państwo zapewni system bezpośredniego wsparcia podmiotom zobowiązanym (pracodawcom). Czy będzie to zapewnienie pomocy prawnej lub innej w przedmiocie przeciwdziałania naruszaniu 
dóbr osobistych, czy darmowe archiwizowanie akt, to już kwestia techniczna. W każdym razie trzeba podkreślić, że nakładanie na małych pracodawców powszechnych i jednakowych obowiązków musi się spotkać co najmniej z ryzykiem naruszenia zasady proporcjonalności. Z kolei proste różnicowanie sytuacji prawnej generuje ryzyko naruszenia zasady równości w stosunku do pracowników. Pogodzenie tych wartości wymaga w moim przekonaniu bezpośredniego zaangażowania państwa.

Problem jest przy tym o tyle większy, że niektórych wartości publicznych nie można scedować na poziom prawa autonomicznego. Przykładowo, archiwizacja akt osobowych wiąże się z ochroną istotnych wartości społecznych, przede wszystkim w kontekście zapewnienia zabezpieczenia socjalnego. Dlatego nie można pozostawić decyzji o tym, czy archiwizować, czy też nie decyzji pracodawcy lub partnerów społecznych.

\section{Ustawowe prawo pracy a zasada subsydiarności}

Poważną barierą w rozwoju prawa ustawowego, skierowanego do nieograniczonej liczby adresatów, jest bariera subsydiarności. Istotą zasady subsydiarności jest to, że nie wolno nakładać na człowieka obowiązków ograniczających jego prawa lub wolności, jeśli cele społeczne można efektywnie osiągnąć innymi metodami bądź jeśli jest to po prostu zbędne. Wdzięcznym przykładem ukazującym związane z tym problemy są wspominane już wyżej świadczenia socjalne.

Istotą świadczeń socjalnych jest bowiem to, że ich przedmiotem jest zaspokajanie potrzeb uznanych za społecznie istotne. O ile sama zasada nie budzi wątpliwości, o tyle występujące w prawie pracy narzędzia jej realizacji zupełnie od nich abstrahują. Uwaga ta dotyczy także dyskusji doktrynalnych, w których nie pojawia się pytanie o obowiązek dbałości o samego siebie przez człowieka. W efekcie mamy do czynienia z rozwiązaniami prawnymi, w których świadczenia o charakterze socjalnym przyznawane są pracownikom bardzo dobrze wynagradzanym. Tym samym powszechnie obowiązujące prawo pracy nakłada na pracodawcę ciężary, pomimo braku uzasadnionej potrzeby społecznej.

Naruszając zasadę subsydiarności, ustawowe prawo pracy często prowadzi także do naruszenia zasady równości. Dobrym przykładem będą przepisy urlopowe. Mechaniczne przyznanie prawa do 26 dni urlopu płatnego abstrahuje od tego, że niektórzy pracownicy nie mają dzieci, są w sile wieku i wykonują pracę nie związaną z potrzebą nadzwyczajnej regeneracji. Tymczasem pracownik posiadający dzieci poświęca swój urlop wypoczynkowy w znacznej części właśnie opiece nad nimi, a nie tylko na wypoczynek własny. Dlatego przy tym samym wymiarze urlopu 
sytuacja osób znajdujących się w istotnie różniej sytuacji jest nierówna. Inne potrzeby urlopowe ma człowiek starszy, a inne młodszy.

Innym przykładem naruszenia zasady subsydiarności w kontekście urlopów, są tzw. świadczenia urlopowe. Każdy pracownik w zakładzie zatrudniającym do dwudziestu pracowników może nabyć prawo do świadczenia urlopowego w tej samej wysokości, niezależnie od uzyskiwanych dochodów. Nabywa je więc także wtedy, gdy nie występuje potrzeba pomocy finansowej.

Wspominane wyżej uwagi prowadzą do wniosku, że powszechnie obowiązujące regulacje prawa pracy napotykają kolejną barierę konstytucyjnoprawną. Inna rzecz, że nie jest jej łatwo zaradzić. Możliwe są - jak się wydaje - trzy możliwe techniki legislacyjne. Pierwsza, to całkowite usunięcie niektórych instytucji z ustawy oraz pozostawienie powyższych kwestii regulacji w prawie autonomicznym. Istnieje jednak realna obawa, że wywoła to nieodwracalny proces obniżenia standardów, czego zresztą nie oceniam z założenia negatywnie.

Druga możliwość jest taka, że ustawa zezwoli na odstąpienie od jej standardów, pod warunkiem pozyskania zgody członków wspólnoty zakładowej. Takie rozwiązanie występuje już obecnie w przypadku odpisów na zakładowy fundusz świadczeń socjalnych oraz decyzji o nietworzeniu funduszu w ogóle.

Wreszcie można rozważyć i takie rozwiązanie, w którym pracodawca sam decyduje o standardzie prawa pracy w ramach dozwolonych przez ustawę. Jednak obniżenie standardów ustawowych wymagałoby obiektywnego uzasadnienia. Takie rozwiązanie wydaje się na pierwszy rzut oka najgorsze. Jednak nie jest to oczywiste. Decyzja pracodawcy w powyższym zakresie nigdy nie będzie dowolna. Takie działanie jest bowiem aktem administracyjnym, skoro decyduje o zakresie stosowania ustawy. Tym samym z założenia podlega ocenie z perspektywy konstytucyjnej aksjologii życia społecznego (sprawiedliwości, proporcjonalności, subsydiarności) z kontrolą sądową włącznie.

A przecież nic nie stoi na przeszkodzie, aby ustawa wprowadziła bardziej zobiektywizowane kryteria oceny decyzji pracodawcy, z opiniowaniem przez pracowników włącznie. Zresztą nic także nie stoi na przeszkodzie temu, aby wskazane wyżej rozwiązania połączyć lub zastosować równolegle.

W każdym razie przesunięcie części decyzji dotyczących ciężarów socjalnych na poziom wspólnot zakładowych w znacznym stopniu obniża ryzyko naruszenia zasady subsydiarności, tak samo zreszta, jak i naruszenia zasady proporcjonalności. Przy czym decentralizacja ma swoją oczywistą granicę, którą jest zapewnienie realizacji istoty publicznych praw pracowniczych. W zakresie wyznaczenia tej istoty prawo ustawowe odgrywa bardzo istotną rolę, której zastąpić się nie da. 


\section{Ustawowe prawo pracy a zasada sprawiedliwości}

Ustawowe prawo pracy miewa także - w moim przekonaniu - większą skłonność do naruszania zasady sprawiedliwości. Czynię przy tym nieco ryzykowne założenie, że bywają niesprawiedliwe rozwiązania prawne, które nie naruszają zasad równości, subsydiarności i proporcjonalności. Być może więc wyodrębnienie zasady sprawiedliwości jako zasady samodzielnej nie jest najszczęśliwsze. Nie przeczy to ogólnemu stwierdzeniu, że perspektywa sprawiedliwości jest co najmniej elementem innych zasad konstytucyjnych.

Przechodząc na grunt ustawowego prawa pracy stwierdzić należy, że realizowanie polityki społecznej kosztem niektórych tylko członków wspólnoty i bez ich udziału, stwarza większe ryzyko wprowadzenia rozwiązań niesprawiedliwych niż dzieje się to w przypadku aktów prawa zakładowego. Powyższe wynika zapewne $\mathrm{z}$ tego, że prawo ustawowe znajduje się pod większym wpływem idei i wyborczych kalkulacji, podczas gdy prawo lokalne jest silniej związane z możliwościami. W efekcie jest tak, że ustawodawca, nie odczuwając bezpośrednio niesprawiedliwości wprowadzonych rozwiązań, nie usuwa błędnych regulacji przez wiele lat.

Przykładów rozwiązań nieracjonalnych jest wiele. Regulacje prawne dotyczące wynagrodzenia chorobowego lub zasiłku chorobowego prowadzą do sytuacji, w której przebywanie na urlopie bądź zwolnieniu chorobowym bywa bardziej opłacalne niż wykonywanie pracy. Przepisy dotyczące ustalania wymiaru urlopu proporcjonalnego są tak skonstruowane, że wymiar urlopu bywa niewspółmierny do okresu zatrudnienia. Wreszcie, błędna $\mathrm{w}$ moim przekonaniu ocena istoty rozwiązania umowy o pracę bez wypowiedzenia doprowadziła do tego, że ustawa nakazuje wypłacanie ekwiwalentu za urlop osobie, która świadomie narusza prawa pracownicze działając na szkodę pracodawcy oraz innych pracowników. Jest to rozwiązanie nie dające się pogodzić z poczuciem sprawiedliwości i w przypadku autonomicznego prawa pracy byłoby zapewne dość szybko skorygowane. $W$ przypadku prawa ustawowego trwa od wielu lat, a doktryna próbuje uzasadnić obowiązujący stan prawny przy dość nikłych argumentach sprawiedliwościowych.

Podobne problemy dotyczą szeregu zagadnień związanych z tzw. szczególną ochroną zatrudnienia. Dobrym przykładem jest tu jawne promowanie powyższej ochrony w przy padku kobiet korzystających z ochrony związkowej w okresach chronionego macierzyństwa. Uwaga ta dotyczy ochrony przed rozwiązaniem umowy bez wypowiedzenia oraz tzw. sprzeciwu w przypadku redukcji indywidulanych. 


\section{Podsumowanie}

Od wielu lat toczy się $\mathrm{w}$ polskiej doktrynie prawa pracy dyskusja nad słabością prawa zakładowego, a w szczególności układów zbiorowych pracy. Wskazuje się przy tym szereg ważkich argumentów, które wyjaśniają ten stan rzeczy. Niniejszy głos jest elementem tej dyskusji, choć pada z innej perspektywy. Wydaje się bowiem, że bardzo poważne i bezkompromisowe potraktowanie zasad konstytucyjności ustaw może doprowadzić do tego, że część instytucji prawa pracy zostanie z nich wyparta. Alternatywnie, technika ustawodawcza będzie katalizatorem rozwoju prawa zakładowego. Stanie się tak wtedy, gdy ustawa wprowadzi rozwiązania widełkowe, pozostawiając partnerom społecznym decyzje co do ostatecznego wyboru standardu prawnego. Wydaje się, że to ostatnie rozwiązanie jest w warunkach słabej tradycji układowej w Polsce najlepsze.

\section{Bibliografia}

Sobczyk A., Wspólnota zakładu pracy jako emanacja społecznej gospodarki rynkowej, „Praca i Zabezpieczenie Społeczne" 2015, z. 4.

\section{Statutory and Non-statutory Labour Law}

\section{Summary}

In the doctrine of Polish law, extensive statutory labour law can be something to be proud of. However, there is evidence to suggest that excessive statutory law can be adversely affecting the growth of the economy and, consequently, the labour market, especially the benefits following from the employment relationship.

Labour law is predominantly social in its nature. Due to the fundamental right of equality before the law to which he is obligated, the state legislator must set equal standards for all employed. However, by doing so, he imposes equal burdens on all employers, thereby failing to take into account their different economic situations. Therefore, the principles of equality and proportionality that apply to employers are violated. The above means that, if the legislator should differentiate social standards, then he will always violate the principle of equality sometimes in relation to the employees and sometimes to the employers. In the conclusion, the author argues that the legislator should strengthen the social dialogue rather than further develop the social legislation, to avoid limitations arising from the principle of equality. 